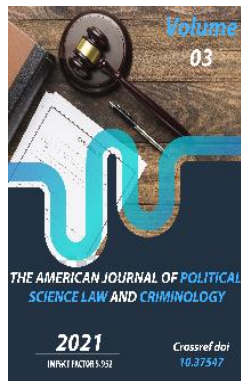

Copyright: Original content from this work may be used under the terms of the creative commons attributes 4.0 licence.

\section{The Concept, Content, Specifics Of Alimony And Some Issues Of Liability For Non-Performance Of Alimony Obligations}

\author{
Abdurasul Bakhodirovich Munojiddinov \\ Independent Researcher At The Department Of Civil Law Of Tashkent State University Of \\ Law, Tashkent, Republic Of Uzbekistan
}

\title{
ABSTRACT
}

This scientific article analyzes the concept, content, specifics of alimony and some issues of liability for non-fulfillment of alimony obligations with the help of legal documents and scientific literature as well.

\section{KEYWORDS}

Alimony, family, liability, marriage, legal relationship, obligation.

\section{INTRODUCTION}

The current level of development of society is characterized by a number of complex socioeconomic problems. At the same time, mutual care between family members, mutual support, mutual financial assistance are of particular importance. The deepening of today's economic reforms, as in many countries around the world, is leading to serious changes in the institution of the family 
and marriage, and people's perceptions of these issues are changing.

The expansion of the global information space, the influx of different views and approaches requires the creation of special legal mechanisms and rules in the field of family values. As a result of changes in Uzbekistan's national values, which were once alien to divorce and annulment, couples are increasingly living apart from each other due to divorce, migration and living in other regions in search of work.

In addition, there are a growing number of cases where alimony recipients are in a difficult financial situation and even have no means of subsistence as a result of delays or nonpayment of alimony payments by their dependents for various reasons. It is sad and intolerable that such vital cases occur mainly against minors and mothers, who are the main source of income for the vulnerable population - alimony payments.

\section{METHODS}

In this case, alimony and obligations to pay them are of great scientific and practical importance. The correct definition of alimony obligations, the introduction of effective mechanisms for determining the income of the alimony payer, the application of prompt and effective measures in the recovery process serve to effectively protect the rights and interests of minors and their mothers. It is known that the word "alimony" is derived from the word "alimentum", which means "food, food, supply". The term originated in ancient Rome, where the state provided financial assistance to the poor and orphans. At that time, alimony was aimed at providing for the daily needs of minors and supporting them until they reached adulthood and selfsufficiency.

\section{RESULTS AND DISCUSSIONS}

Opinions about this institution of family law have changed in terms of specific circumstances and legal regulation. In particular, in the 1920s, with the development of the social security surrogate and the social security system, there was an idea that alimony obligations would disappear as a legal mechanism [1]. This theory was rejected at the time, but it should be noted that there is a link between alimony obligations and the level of development of the social security system, both of which have the same goal, namely to provide benefits to the disabled.

Today, alimony is one of the most important categories of modern family law. Although the importance of this institution is high, there is no legal definition of alimony obligations in the Family Code and other legislation. At one time, a number of legal scholars expressed different views on the "Category of alimony obligations". Many authors who have analyzed this problem have interpreted the meaning of the term "alimony obligations" in terms of obligations. In particular, A.I. Pergamint interpreted alimony obligations as a statutory obligation by a family member to provide for a needy family member [2, p.6]. N.M. Ershova suggested not to use the term "obligation" in relation to alimony. He notes that the law sets rules on duty, not on obligation [3, p.19].

Nowadays, experts are proposing a new modern definition of alimony obligations. According to E.Yu. Kostyuchenko, it is expedient to use the term "obligation" rather than "duty" in relation to alimony legal relations. Because obligation is one of the 
manifestations of duty. The concept of obligation allows to express the subjective right of one person to another person - the right to demand funds from the obligor [4, p.7].

S.P. Grishaev interprets alimony obligations as a special type of obligation that arises on the basis of imperative norms of family law and is characterized by a complex subjective structure and an element of publicity. According to him, alimony obligations are a legal relationship arising from the agreement of the parties or a court decision, in which one member of the family must provide maintenance to another member, and a member of the needy family has the right to demand such provision [5]. According to O.A. Davydova, alimony obligations are a legal relationship, according to which one member of the family (debtor-alimony payer) has the right to claim alimony for the benefit of another family member (creditor - age, disability or need - alimony recipient) undertakes certain actions to provide funds for maintenance (alimony) in the amount specified in the agreement: payment of money, transfer of other property or other means of alimony, and the creditor has the right to demand from the debtor to fulfill this obligation [6, p.10].

This definition more broadly reflects the essence of alimony obligations, and thus allows a comprehensive coverage of the subjective structure of alimony relations, as well as the definition of the rights and obligations of the parties.

The concept of "obligation" in family law and civil law differs on a number of grounds.

1. In civil law, an "obligation" is a legal relationship in which the participants are strangers, as well as legal entities and public organizations. The parties to this legal relationship are always the debtor and the creditor. In alimony relations, the "obligation" is the right and the obligatory party, not any foreign citizens, but only family members (needy or incapable of work).

2. The basis of civil liability is contracts, damages, unjust enrichment, unilateral actions, etc. Alimony legal relationship between relatives, spouses is required to comply with a number of conditions: the age of majority, incapacity for work or the need for a entitled subject and the ability to provide support by the compulsory subject.

3. Civil legal obligation may be changed. For example, an innovation (cancellation of an obligation with renewal), as well as a transfer, cancellation in the payment of waiver fees. Alimony legal relations cannot be changed or terminated on these grounds. In the first instance, alimony obligations may be terminated on the grounds of the child's coming of age, the death of the payer or alimony recipient, and other grounds beyond the control of the parties.

4. A civil legal obligation, as a rule, acquires a fixed term. Family law relationships, on the other hand, are characterized by longevity. Due to the fact that claims for the payment of alimony are personal and long, they are not subject to the statute of limitations.

The legal norms of some foreign countries, such as the Chinese Civil Code, which came into force on January 1, 2021, do not include the generally accepted concept of alimony obligations. However, this code provides for the obligation of a able-bodied member of the family to provide for the needy and disabled 
members of the family. Such a structure of family law (the absence of a separate institution called alimony obligations) is traditional for China. The obligation to provide, that is, to provide for the need for accommodation, food and other necessities of life, arises in able-bodied members of the family in respect of children and the elderly. In Germany, the concepts of "alimony" and "supply" are used interchangeably [7, p.410].

According to the legislation of the Republic of Uzbekistan, alimony relations are, by their nature, property relations. Because it implies the transfer of certain property. The concept of alimony obligations implies the provision and financial support of certain categories of persons and arises from the family-legal relationship for the payer. Therefore, these relations will have the property of personal property value and free realization. This implies the transfer of funds from the payer to the recipient, if there are appropriate grounds. The parties to the legal relationship of alimony are the payer and the recipient. This requires the payer to be able and able to pay certain amounts independently. That is why the obligation to pay alimony is imposed on adults who are able to work. Based on the grounds established by law, if necessary, the obligation to pay alimony may also be imposed on minors who have entered into marriage or are emontsipated.

As a rule, the object of alimony obligations is the voluntary or compulsory transfer of the relevant funds by the payer. The right to demand maintenance by the alimony recipient represents the content of alimony obligations. Depending on the category of subjects participating in alimony obligations, alimony obligations can be divided into the following types.

1. Alimony obligations between parents and children;

2. Alimony obligations between a spouse and an ex-spouse;

3. Alimony obligations between other relatives (sisters, brothers, grandparents and grandchildren, as well as step-parents and step-sons) [8, p.450].

Alimony is collected from the payer's funds and includes:

1. Income;

2. Cash available on the account of the credit institution;

3. Funds provided to commercial and noncommercial legal entities on the basis of civil law contracts, except for contracts providing for the transfer of property rights.

4. Any other property of the alimony payer [ 9 , p.300].

One of the problematic aspects of the alimony relationship is that the legislation does not set a minimum amount of alimony. This is primarily due to the fact that the state does not have appropriate mechanisms to force people who do not want to work or do not have adequate working hours to work. M.V.Antokolskaya stressed that if parents do not have sufficient income and property, it is not allowed to force them to work for alimony. Because it leads to a violation of the Constitution and human rights. In this regard, there is a problem with the existence of a mechanism for the implementation of this obligation, if the obligation of parents to provide for their children is enshrined in legal documents, which are very serious. The fact that there is no 
sanction for non-fulfillment of an obligation has become not a legal obligation, but a moral obligation to feed and clothe children. The disparity is that under current law, parents who fail to comply with this obligation cannot be deprived of parental rights.

In our opinion, it is necessary to take the following measures to get out of this situation and eliminate this imbalance. The grounds for deprivation of parental rights should be that the parent fails to fulfill his or her obligations to his or her children without good reason and refuses to do so.

In this regard, it is expedient to clarify the rules of refusal to pay alimony in Article 79 of the Family Code, and to provide for cases of inability to pay alimony for valid reasons.

Motherhood and childhood, the family is under the protection of the state, and therefore the state should set a minimum amount of alimony in the legislation. For example, the minimum amount of alimony payments for the maintenance of one child should be equal to the minimum value of the marriage, taking into account the fact that he is a minor [10, p.230].

In practice, the increase in the number of unregistered marriages requires special provisions in the legislation to protect the rights of mothers and children born out of wedlock (without a legal marriage). At the same time, it is necessary to equate the rights of children born out of wedlock with the rights of children born in legal marriage in all respects. This should take into account the pregnancy of the mother who is not legally married to the child's father and the right to child support until the child reaches the age of three, when the child's father acknowledges his paternity or the paternity is determined by a court [11]. The purpose of this procedure is to equate the rights of children born out of wedlock with the status of children born out of wedlock. In this way, not only the right of children born out of wedlock to receive financial support from their biological father is protected, but also his standard of living and upbringing will change to a certain extent for the better.

Current family law provides for the obligation of the child's father to provide for the mother during pregnancy and until the child reaches the age of 3 , as well as during or after the marriage. The mother, who is not legally married to the child's father, does not have the right to file a claim for maintenance in this situation, regardless of the period of cohabitation [12, p.210]. In this regard, the Family Code should include a provision providing for the right of an unmarried woman to claim alimony during pregnancy and until the child reaches the age of 3 , if the father recognizes paternity or paternity is established by a court order. This measure also serves to ensure the rights of women living today without legal marriage.

A number of authors in their research have focused on the comprehensive legal regulation of the legal status of the stepfather (stepmother) in the family. Such an arrangement is especially relevant in families where the parents are incomplete, that is, when the child is not the mother (father). Because the child's relationship with the stepfather (stepmother) may go beyond the scope of family law regulation. Therefore, it is expedient to include in the legal norms governing the registration of marriages the provision that spouses must provide information about the presence of children 
when applying, and that one of the spouses must have a minor child. Such information may include:

- Information about the child's second legal father (mother) (survival, death, deprivation of parental rights, participation in the maintenance and upbringing of the child, etc.);

- Information about other persons involved in the maintenance and upbringing of the minor (grandmother, grandfather, etc.) and the place of residence of the child (living with his father, grandmother or other relatives or in an orphanage, boarding school);

- A joint decision with the future spouse on the maintenance and upbringing of the child (only upbringing, only maintenance) or, conversely, the decision to perform such an obligation in the future by the child's mother (father).

In this case, the information about the participation of the spouses in the upbringing and maintenance of the child (only upbringing, only maintenance) of the future stepfather (stepmother) should be recorded in the civil status record book. At the same time, the record of the upbringing and maintenance of the child, together with the record of the marriage, serves as the basis for the emergence of the relevant right in the relationship between the stepfather (stepmother) and the stepchild. These records also play an important role in certain situations (in the absence of a second legal parent) and when a stepfather (stepmother) is recognized as a surrogate parent for a minor.

In this regard, the following amendments should be made to the Family Code:
1. Establishment of the rights and obligations of the stepfather (stepmother) on the upbringing and maintenance of minor stepchildren during the marriage of the child with the mother (father). At the same time, it is necessary to clearly define the voluntariness, scope and duration of rights and obligations;

2. Grounds for recognition of a stepmother (stepfather) as a surrogate parent and determination of the legal status of such persons. The Family Code of the Republic of Uzbekistan, in contrast to the previous family legislation, does not provide for the payment of alimony in the event that the foster parents in practice waive the obligation to further care and support. There are some opinions in this regard in the legal literature. In particular, V.M. Antokolskaya supports such an approach, emphasizing that educators who are not relatives are not obliged to bring up the child financially. They carry out the work of raising a child in the way of their own free will and noble purpose. Therefore, the law should not allow someone to use his human actions against himself [13, p.30].

Another problematic aspect related to alimony obligations is related to non-enforcement of court decisions on alimony.

According to Article 122 of the Criminal Code of the Republic of Uzbekistan, a parent refuses to comply with a court decision on the payment of child support, disability and incapacity for work for more than two months, despite the imposition of administrative penalties. is punishable by up to two years of correctional labor or up to one year of imprisonment.

However, the current legislation does not provide for clear criteria for intentional evasion 
of the obligation to pay alimony, and those who evade the payment of alimony are not prosecuted. In addition, the current legislation provides for the refusal to pay alimony only in connection with the non-fulfillment of the obligation to collect alimony on the basis of a court decision or order. However, the liability of a debtor who is required to pay alimony under a notarized agreement for nonperformance of this obligation is not provided for in the legislation on criminal and administrative liability. In our opinion, such a norm should be taken into account in the Code of Administrative Responsibility and the Criminal Code of the Republic of Uzbekistan.

However, in the event that the debtor is not working or unable to find a job, there are insufficient legal mechanisms for the bailiff to send him to the appropriate employment centers for employment. If a person who refuses to pay alimony wants to get a job in order to ensure the payment of alimony after being prosecuted, this situation will have a negative impact. In addition, the presence of a conviction in the debtor may also have a negative impact on the future of the child of his close relative. In this regard, the relevant organizations will need to establish a system of creation and maintenance of separate states for individuals who are obliged to pay alimony in state-owned enterprises and institutions.

\section{CONCLUSION}

It should be noted that the protection of the rights and legitimate interests of children is one of its important tasks before the state. Thus, temporary restriction of the right to drive a vehicle (until alimony is paid) by parents who have not fulfilled their obligation to provide for their child can be an effective and efficient measure. After all, today it is known that alimony debtors drive a car on the basis of a power of attorney, registering it in the name of others. In international practice, there is a practice of restricting the non-property rights of serious debtors, including the right to drive vehicles, under video surveillance.

Therefore, it would be expedient to introduce in our national legislation a procedure for suspension of the debtor's driver's license for alimony obligations until the payment of alimony.

\section{REFERENCES}

1. Pischikov V.A. Rastorzheniye braka: razdel imushchestva, prava detey, alimenty, obraztsy dokumentov. - M., 2005.

2. Pergament A.I. Alimentnyye obyazatel'stva po sovetskomu pravu. M., 1951. p.6.

3. Yershova N.M. Imushchestvennyye otnosheniya v sem'ye. - M., 1979. p.19.

4. Kostyuchenko Ye.YU. Alimentnyye obyazatel'stva roditeley i detey po zakonodatel'stvu Rossii i Germanii: sravnitel'no-pravovoy analiz. - Smolensk, 2010. p.7.

5. Grishayev S.P. Alimentnyye obyazatel'stva // SPS «Konsul'tantPlyus». 2011.

6. Davydova O.A. Pravovoye regulirovaniye alimentnykh otnosheniy $v$ semeynom prave Rossiyskoy Federatsii: dis. ... kand. yurid. nauk. - Rostov n/D., 2005. p.10, 47.

7. Fayzer V. V. Po stateynyy kommentariy k Semeynomu kodeksu Rossiyskoy Federatsii.- Rosto v-na-Donu: Feniks, 2012. $-410 \mathrm{p}$.

8. Belov V. A. Alimenty v semeynom prave. M.: No ta, 2013. - 450 p.

9. Alekseyev S. S. Alimentnyye obyazatel'stva. - M.: BEK, 2012. - 300 p. 
10. Pergament A. I. Osno vnyye pro blemy semeyno go prava / A. I. Pergament. - M.:

Pravo, 2014. - $230 \mathrm{p}$.

11. Esonova Z.N. Procedural features of consideration of disputes related to the upbringing of children in a civil court. Yurid. fan. doc. diss ... avtoref. - Tashkent, TSJI. 2010.

12. Sergeyeva A.P. Semeynoye pravo. - M.: Vedi, 2013. - $210 \mathrm{p}$.

13. Antokol'skaya M. V. Pravo vyye pro blemy vzyskaniya alimento v: avto ref. dis. ... kand. yurid. nauk: -- Omsk, SIBIT. 2013. $30 \mathrm{p}$. 